\title{
Evaluation of Figure Drawing Skills of Art Students in Tertiary Institutions. A Case Study of Bolgatanga Polytechnic
}

\author{
Adjei Akuoko Daniel* Amenyo Dzikunu-Bansah \\ Department of Industrial Art, Bolgatanga Polytechnic, P. O. Box 767, \\ Bolgatanga, Upper East Region, Ghana
}

\begin{abstract}
Figure drawing is at the centre of many visual art programmes in the tertiary institutions in Ghana such as Fashion Designing, Sculpture, Painting and Graphic Designing. This is important because careers in these programmes requires the use of knowledge on correct representation of the human figure. Fortunately, the second cycle Visual Art and General Art programmes syllabi mandates the teaching of figure drawing. Unfortunately, students who are admitted to pursue various programme options in Industrial Art at the Bolgatanga Polytechnic are unable to demonstrate good skill in the drawing of the human figure. This paper therefore sort to identify areas in figure drawing which pose challenging to students. The study was carried out between 2014 and 2017 with the level 100 students of Industrial Art department of the Bolgatanga Polytechnic. The students were made to produce several human figure drawings each week and these drawings were then scored and the various infractions recorded. The study revealed that human figure drawing is a general problem for graduates of the second cycle visual art programme. Areas in the human figure drawing which was very difficult for students to handle included the facial features as well as the fingers. The study recommends that the Ghana Art Teachers Association takes a look at this trend and advice teachers to take lessons of figure drawing serious. Also, figure drawing teachers in Tertiary institutions needs to start the lessons of figure drawing from the basics.
\end{abstract}

Keywords: Adult figure drawings, draw-a-person, human figure drawing, industrial art.

DOI: $10.7176 / \mathrm{JEP} / 10-8-09$

Publication date:March $31^{\text {st }} 2019$

\section{Introduction}

\subsection{Art Education in Ghana}

The enrolment of Ghanaian children in the Ghanaian formal educational system dates back to the colonial era. The castles were the first areas where schooling begun with the Cape Coast castle being the first in 1529. These schools were to educate the Portuguese mulatto children. No ordinary Ghanaian child without link to the Portuguese was educated under this system. When the Christian Missionaries (Basel, Wesleyan, Breman, the Roman Catholic and the African Methodist Episcopal Zion) took over the administration of the schools, education was extended to the reach of other Ghanaians who were not mulattos, however, the teaching of art was not permitted. They considered Art to be intrinsically linked to the cultures of the Ghanaian which they hitherto considered to be fetishistic (Annor 1989 as cited in Kassah \& Kemevor, 2016).

In 1919, Art was introduced into the educational system and this brought about rapid transformations which led to the establishment of the first Art Department in Achimota School in 1927. The teaching of Art in this school begun with the appointment of two Europeans, G. A. Stevens and Maclaren, as art masters. These men taught much theory until Gabriel Pippet was appointed as Art master. He introduced woodcarving and basketry as courses (Antubam 1963 as cited in Edusei, 2004). The first African to be appointed as Art master was Mr. Meyerowitz, a South African in 1936. He developed a three-year specialist course in Art and craft teaching at the Achimota School. Under his leadership, the courses in Art were expanded to include Basketry, Pottery, Weaving, Traditional Woodcarving, Terracotta, Modelling, Mural Painting and Brick \& Tile Making. After the death of Mr. Meyerowitz, Mrs Eva Meyerowitz took over for a brief period followed by Mr Machendricks (Edusei, 2004).

In 1952, the Visual Arts Teacher education was transferred from Achimota School to the College of Technology and later, to Winneba (present Art Education Department at the University of Education Winneba). Later, four teacher training colleges were equipped to train teachers in Art and these included Asokore, Peki, Komenda and St. John Bosco Training College in Navrongo (Edusei, 1991)

\subsection{Visual Arts in second cycle schools in Ghana.}

The history of this educational structure dates back to 1973, when as part of the report submitted by the Dzobo committee during the Presidency of Col. Ignatius Kutu Acheampong, it was recommended that secondary education should be structured into Junior Secondary School (JHS) and Senior Secondary School (SSS). In 1987, there was an educational reform which placed Secondary School programmes into five curriculum, namely: General Arts and Science, Agriculture, Business, Technical and Vocational (Williams, 1964, as cited in Adugyamfi, Donkor, \& Addo, 2016). The visual arts curriculum for Senior Secondary School is made up of eight (8) subjects, namely Basketry, Jewellery, Ceramics, Graphic Design, Leatherwork, Picture Making, Sculpture, 
Textiles, and a compulsory General Knowledge in Art (GKA).

In the second cycle Visual Art education programme, a second cycle educational institution could offer to students various Visual Art subject combinations. However, the Ghana Education Service policy guideline indicates that a school needs to have at least one 2-dimensional Visual Art course (Textile Design, Graphic Design, Picture Making) and one 3-dimentional Visual Art subject (Basketry, ceramics, Jewellery, Sculpture, Leatherwork) in addition to General Knowledge in Art, which is a compulsory subject for all Art students including those pursuing General Art Studies (GWSonlineGH, n.d.).

\subsection{Figure drawing}

Drawing is an integral part of the scope of the Visual Art Education in Ghana and this is to help foster creativity in the students to help solve problems. This is also to develop the intuitive nature of the students (Edusei, 2004). A student who has passed through the General Knowledge in Art subject is required to be able to draw the human figure proportionately as well as sketch human figures in action. The syllabus indicates that the teaching of the human figure drawing should begin with a discussion on the human body, after which teachers are to guide students in the acquisition of the skill of drawing the human figure. It is also a requirement that students are to make series of human figure drawings (Amenuke, et al. 1999). These requirements are to ensure that the student after successfully completing this subject will know how to draw the human figure accurately. The syllabi for all the 2dimensional Visual Art courses lay emphasis on the point that the student should be taught the drawing of the human figure so that they will be able to apply the skill in the execution of works. The syllabus for sculpture makes it emphatic that students should practice the modelling of human figures using different materials (Curriculum Research Development Division, 2010).

Although the syllabi is emphatic on what should be taught in terms of human figure drawing, the topics would not be taught if the teacher does not know how to draw himself/herself. A study by Boafo on how Creative Art is taught in Junior High Schools in the Ashanti Region of Ghana established that $80 \%$ of teachers of the Creative Art subject found it difficult to present lessons well to pupils. This is partially due to the fact that $91 \%$ of these teachers are not trained to teach Art but are currently doing so. This indicates that the teachers lack the skill which they are required to impart. When the teachers were asked what they do when they get to a difficult topic, $82.1 \%$ indicating that they skip these topics and move on to different topics while only $17.9 \%$ indicated that they seek for help (Boafo, 2010). If teachers do not teach topics which are difficult to them, it is probable that the students might not learn that particular topic on their own.

\subsection{Art in Bolgatanga Polytechnic}

The Industrial Art Department of Bolgatanga Polytechnic was established in 2008 to train and award Higher National Diplomas in Fashion Design and Textiles, Graphic Design, Ceramics, Sculpture, Painting \& Decoration, and leather works. Students who are admitted into these programmes are from various second cycle institutions dotted around the country as well as those who possess $\mathrm{O}$ level or other professional certificates (Bolgatanga Polytechnic, 2018; Legonconnect, 2017).

At the entry level of the Industrial Art programme, it is mandatory for students to go through courses in some key subject areas in Visual Art and among these courses is General Drawing. This equips the student with the requisite skills in human figure drawing, landscape drawing as well as the drawing of objects in the environment (Bolgatanga Polytechnic, 2012). The drawing skills and knowledge exhibited by students admitted into level 100 has not been impressive even though these students are required by the second cycle visual art programme syllabi to learn how to draw including the human figure. The inability of students to draw simple human figures makes it challenging for lecturers who teach courses related to the human figure. For this reason, it was the intention of the researchers to assess the human figure drawing skill of the students in order to establish the areas which pose challenging. The study will help drawing lecturers to know the teaching and learning methods to adopt in order to arrive at the desired results faster.

\section{Methodology}

The survey was conducted in the Bolgatanga Polytechnic with students pursuing the Industrial Art programme comprising of Fashion Design \& Textiles, Sculpture and Graphic Design. The study was conducted within four (4) consecutive years; 2014, 2015, 2016 and 2017 with the level 100 students only, between the months of October and November each year. In 2014, 64 drawings were produced by the 26 students. The number of drawings increased with increment in enrolment as shown in table 1. 
Table 1: Number of drawings per year

\begin{tabular}{ccccc}
\hline Year & Number of Students & Males & Females & Number of drawings \\
\hline 2014 & 26 & 6 & 20 & 64 \\
2015 & 22 & 6 & 16 & 79 \\
2016 & 38 & 14 & 24 & 113 \\
2017 & 48 & 18 & 30 & 120 \\
\hline Total & 126 & 44 & 90 & 376 \\
\hline
\end{tabular}

\subsection{The drawing sessions}

Since we wanted to access their ability to draw the human figure, the draw-a-person test was adopted for the study and four themes were given the students, namely 'draw yourself', 'draw your father', 'draw your mother', and 'draw your nuclear family'. All these were to enable the students draw the male and female human figures in different contexts so as to identify the issues which run through their drawings. No further instructions were given to the students except that they are to draw full figures without the use of sticks. Each drawing session lasted for 30 minutes on Tuesdays and the students were provided white A4 bond paper and pencils.

\subsection{Observation}

To gain insight into how the students draw, we observed and recorded reactions of students before and during the drawing sessions. It was observed that some students quickly searched for their smart phones to draw pictures from it. Others also pulled out magazines or books which had images in it. However, they were not allowed to draw images from phones or books. The use of erasers were rampant, especially in the first ten minutes of every drawing session.

\subsection{Scoring of drawings}

A scoring scale was developed for scoring the drawings. The scale analysed 16 different aspects of each drawing (such as specific body parts, clothing and use of space) for various criteria including presence or absence, position, proportion and detail. To reduce scoring biases, each drawing was scored separately by the two researches and the results were then compared, where there are disparities, discussions are held before a final decision is taking. The scores for each drawing was recorded and the SPSS software was then used for computing the results obtained.

\section{Results and discussions}

\subsection{Background of students}

The students were from Second Cycle schools in seven (7) out of the ten (10) regions in Ghana. The region which had most students $(72.2 \%)$ was the resident region of the Bolgatanga Polytechnic, which is Upper East region. The Northern region was second with $9.5 \%$ whilst the Volta region had the least number of students as presented in figure 1. The regions without representation were the Western, Brong Ahafo and Central.

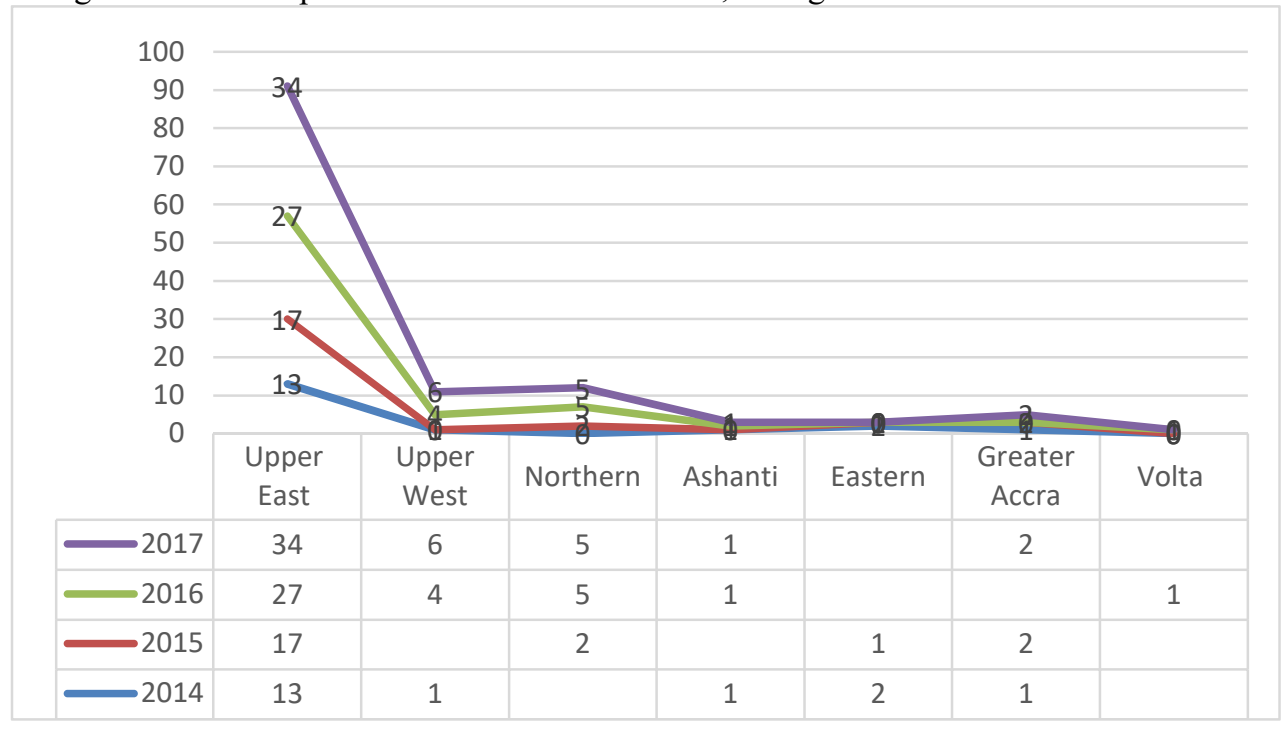

Figure. 1: Regional distribution of level 100 students

There are three categories of second cycle schools (Senior High School (SHS), Senior High Technical School (SHTS) and the Technical Institution (TI)) in Ghana and all these have programmes which teaches figure drawing. The students from the SHS's and TI's were $42.5 \%$ each, as indicated in table 2. 
Table 2: Second cycle institutions of students

\begin{tabular}{lrrrrrc}
\hline Type of school & 2014 & 2015 & 2016 & 2017 & Total & $\%$ \\
\hline Senior High School (SHS) & 8 & 9 & 11 & 29 & 57 & 42.5 \\
Senior High Technical School (SHTS) & 3 & 1 & 10 & 6 & 20 & 15.0 \\
Technical Institute (TI) & 15 & 12 & 17 & 13 & 57 & 42.5 \\
\hline Total & 26 & 22 & 38 & 48 & 134 & $100 \%$ \\
\hline
\end{tabular}

The study involved 134 students of which 90 were females while the remaining 44 were males (Table 1). The drawings made by the males summed up to $110(29.3 \%)$ while those of the females were $266(70.7 \%)$.

\subsection{Treatment of head and facial features}

\subsubsection{Shape of head}

Two distinct shaped were identified in the drawings; oval and round. The oval head shapes constituted $58.8 \%$ while the remaining $41.2 \%$ had roundish heads. In terms of proportion, $48.1 \%$ of the drawings were proportional to the size of the body while $51.9 \%$ were disproportional. In most cases, these disproportional head shapes were very large and resting on tiny necks or on necks which were as broad as the shoulder line. In each category of students, the number of drawing with oval heads were more than those with round heads. Drawings from Technical Institution students had the highest oval heads (61.1\%) while SHS and Secondary Technical had 53.3\% and $48 \%$ respectively.

\subsubsection{Eyes}

Regarding the drawing of eyes, $96.3 \%$ of the drawings had two eyes while only $3.7 \%$ had only one eye as shown in figure 2. A cross tabulation indicated that $5.6 \%$ and $3.8 \%$ of the drawings from Technical and Secondary students respectively had one eye. Generally the eyes were indicated with a dot encircled by an oval. Most of the drawings had both eyes placed wide apart. Some eyes were placed on the forehead.

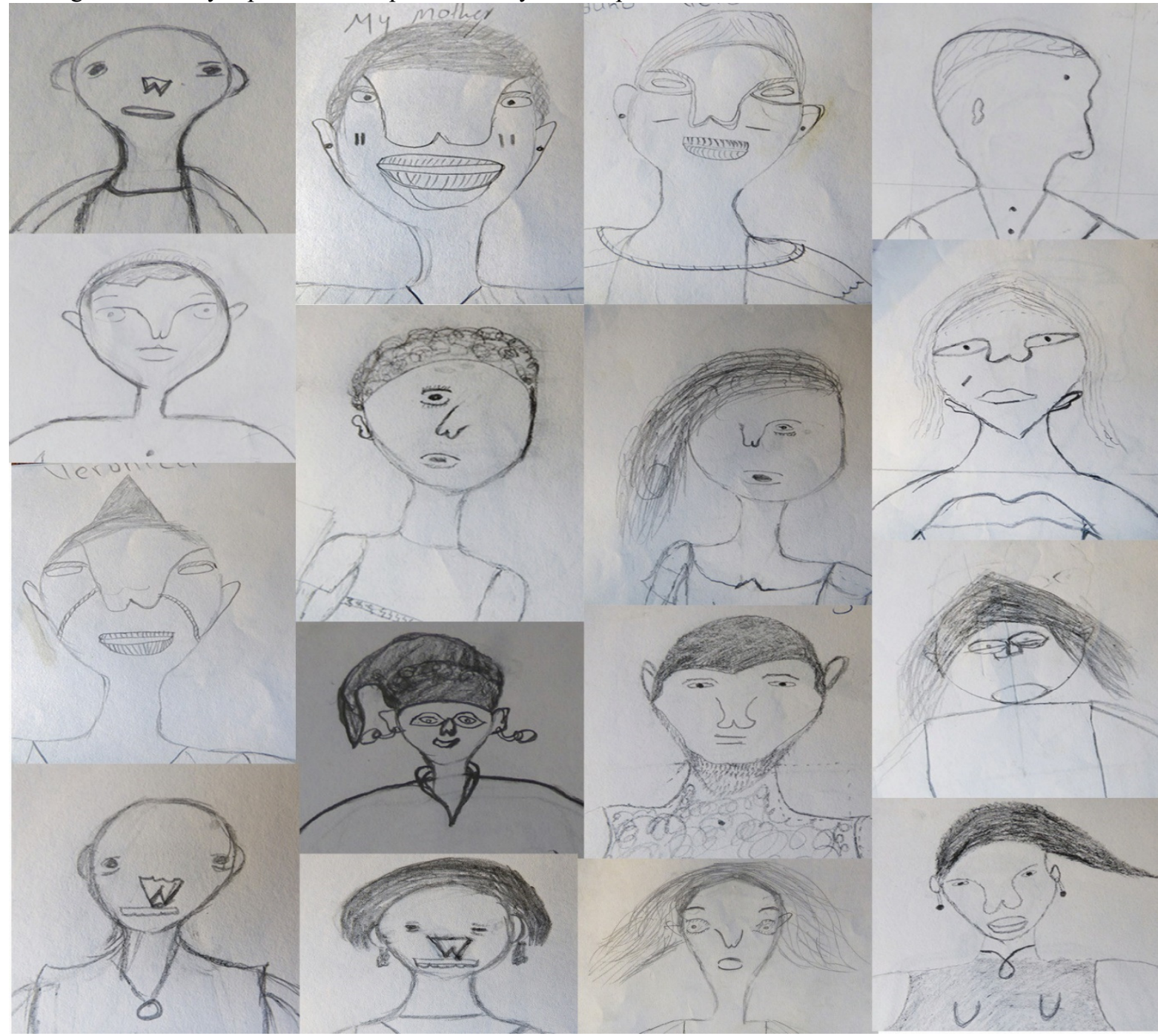

Figure 2: Sample of facial features 


\subsubsection{Nose}

Out of the 376 drawings, only 99 (26.3\%) had correctly drawn nose which were proportional to the size of heads drawn. Most of the noses drawn (73.7\%) were either too narrow, too broad or simply indicated with a double-V (W) or double-U. In some few cases, the letter " $m$ " was used to represent the nose as can be seen in figures 2 and 3.

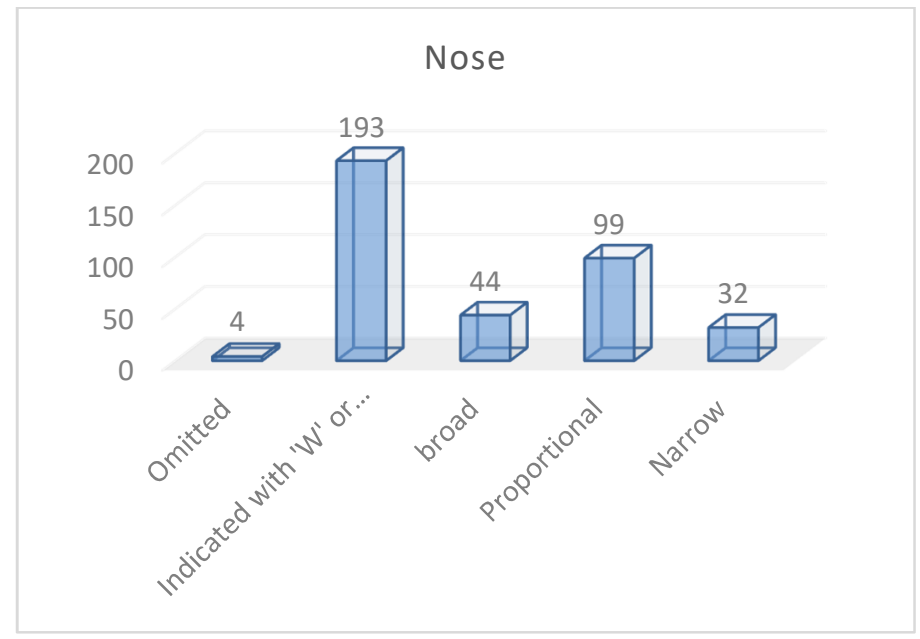

\subsubsection{Lips}

Figure 3: Treatment of nose

The drawing of lips was another area of concern. Works that had lips correctly represented were $192(51.1 \%)$ whilst the remaining drawings either did not have lips indicated at all (2.1\%), or had a line or two as lips (30.6\%) as shown in figure 4 . The remaining $15.2 \%$ used circles or ovals to indicate the lips. There were no significant difference between the drawings produced by the students from the different schools.

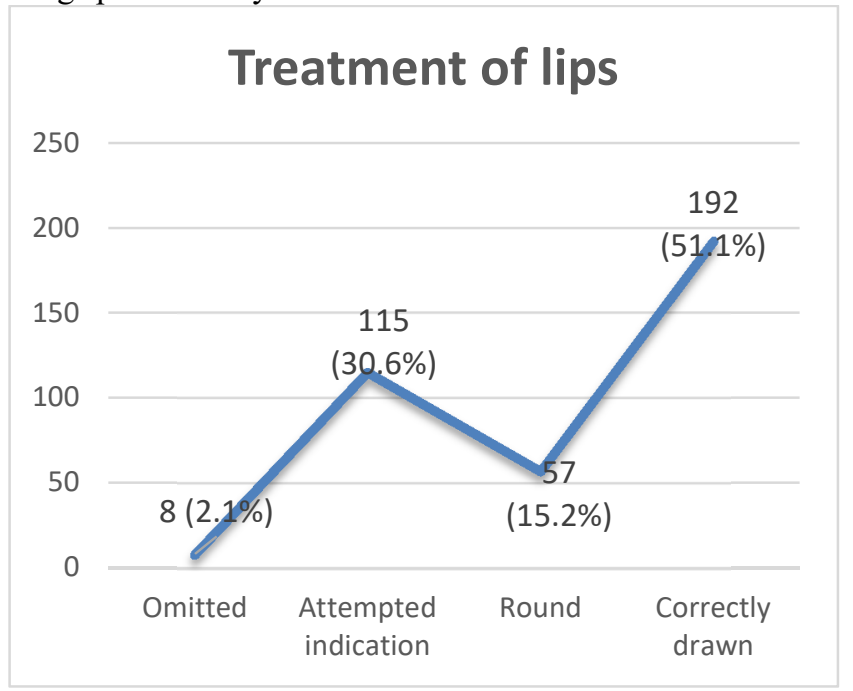

\subsubsection{Ears}

Figure 4: Treatment of lips

Regarding the drawing of ears, $45.7 \%$ of the drawings had correctly drawn ears, although $51.9 \%$ of the ears drawn were not proportional to the size of heads drawn. Students who could not illustrate the ears well used simple marks in the form or curves. This constituted $35.6 \%$ of the drawings and $18.6 \%$ of the drawings had absolutely no ears indicated.

\subsection{Treatment of Neck}

Out of the 376 figure drawings produced, $98.1 \%$ had necks indicated while 7 , representing $1.9 \%$ omitted the necks. Out of the drawings with necks indicated, a chunk of them were not proportional to the size of the bodies drawn. $5.6 \%$ of the drawings had elongated necks (figures 5 and 6). Some of the lengths of these elongated necks were as long as the height of the upper torso. Others necks were too broad (14.9\%) or too narrow (7.4\%) for the size of figures drawn. However, $70.2 \%$ of the drawings had proportionally drawn necks. Out of the 106 drawings produced by students from SHS, 79.2\% were proportional as compared to $68.9 \%$ and $62.2 \%$ from Technical 
Institutions and Secondary Technical Schools respectively.

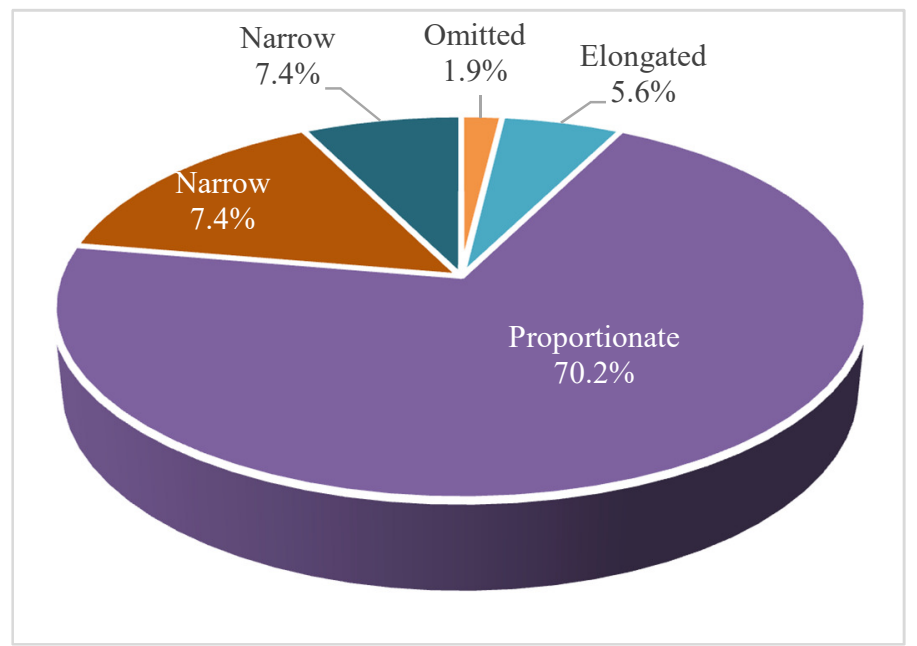

Figure. 5: Treatment of neck

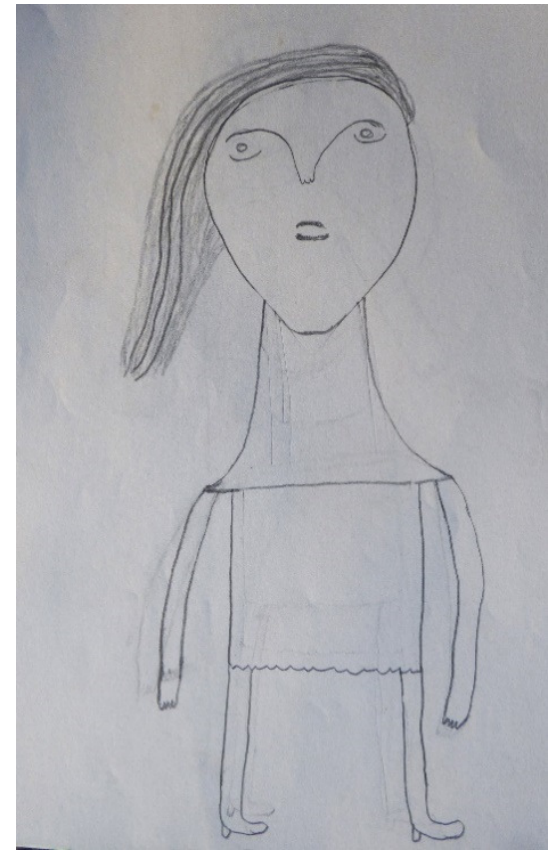

Figure 6: Elongated neck

\subsection{Arms}

A total of $39.4 \%$ drew their arms proportionately. Institutional cross tabulation revealed that $45.3 \%$ of the drawings produced by students from the SHS were proportional as compared to $41.7 \%$ from Technical Institutions and $29.1 \%$ from SHTS. This indicates that more students from the SHTS significantly had more errors in the drawing of arms than the other category of students. The rest had either the arms omitted, elongated, shortened or hidden behind the figure. Figure drawings with omitted arms constituted $1.9 \%$ of the total drawings (figure 7). Some of the students were in the habit of omitting the arms of their human figures. Probably, these students find it challenging to draw the arms and so found it prudent to hide them. Some figures had shortened limbs (46\%) and some of these fingers were drawn just after the elbows.

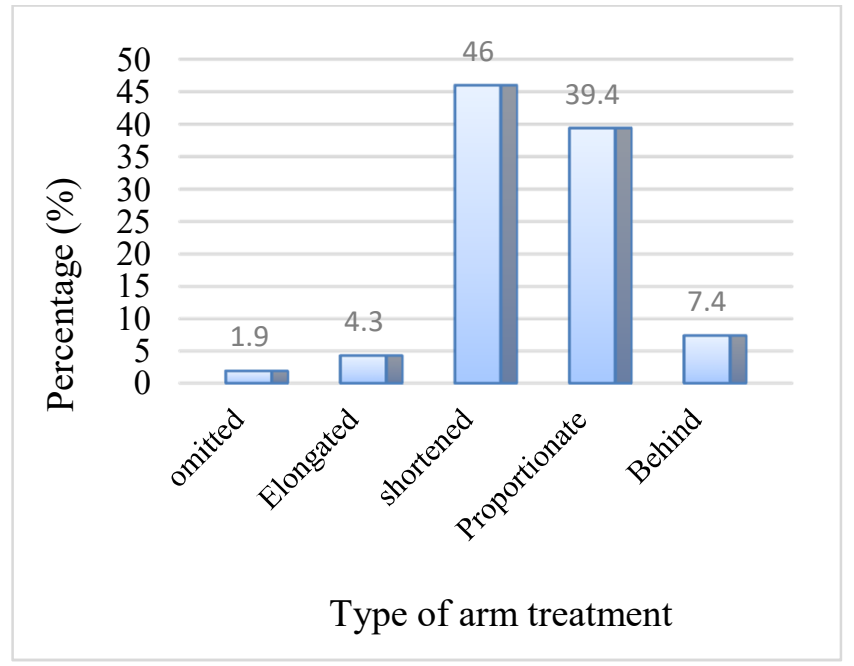

Figure 7: Treatment of arms

\subsection{Fingers}

The drawing of fingers were generally problematic. As shown in figure 8 , only $5.3 \%$ had fingers which were proportional to the size of their figures. As many as $19.1 \%$ failed to indicate fingers on their drawings. $182(48.4 \%)$ of them either deliberately or unconsciously hid the fingers on their figure drawings.

Some students left the drawing of the arms incomplete, making it not necessary to add fingers. Others created the illusion of hands-in-pockets or simply hid the fingers behind the figure as a choice of pose. Majority (54.4\%) 
of the drawings produced by these students had hidden fingers. No fingers drawn by the students from Technical Institutions were proportional to the size of figure drawn. Averagely, the students from Secondary Technical Schools had more correctly drawn fingers than the students from the other schools.

In works which had fingers, these were usually represented with zigzag marks just after the wrist area, others made attempts at representing the fingers by joining curves just at the position that would have been appropriate for positioning the elbow. However, such attempts in one way or the other ended up in fingers without thumbs or two to four fingers of equal heights on the wrist. This revelation could be that the students are not taught how to draw fingers at their various second cycle schools or probably they have forgotten how to represent them. It could also mean that since some of their figures were small in size, they could not have clearly represented all the fingers on the figure.

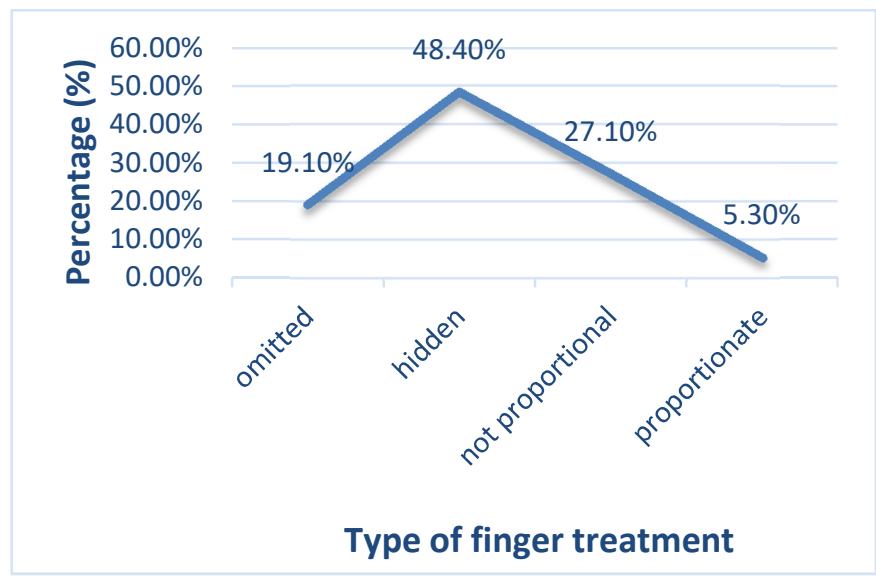

Figure 8: Treatment of fingers

\subsection{Lower limbs}

Out of the 376 drawings, $0.8 \%$ failed to show lower limbs in their drawings, $58 \%$ of the limbs were proportionate to the body sizes. The remaining $41.2 \%$ either shortened or elongated the limbs (figures 9 and 10). While some students seemed to be out of enough paper space to enable them provide full limbs, others seemed to adjust the limbs to suit the not-enough space left for the limbs. The drawing of such limbs consequently looked shortened possibly in an attempt to "manage" the remaining "small space". Some of the shortened limbs were drawn to simply go down till it run out of paper-space, giving the illusion of cut-off limbs. A cross tabulation indicated that more drawings $(43.9 \%)$ made by students from the Technical Institutions had shortened lower limbs as opposed to $34 \%$ and $17.8 \%$ from SHS and SHTS respectively.

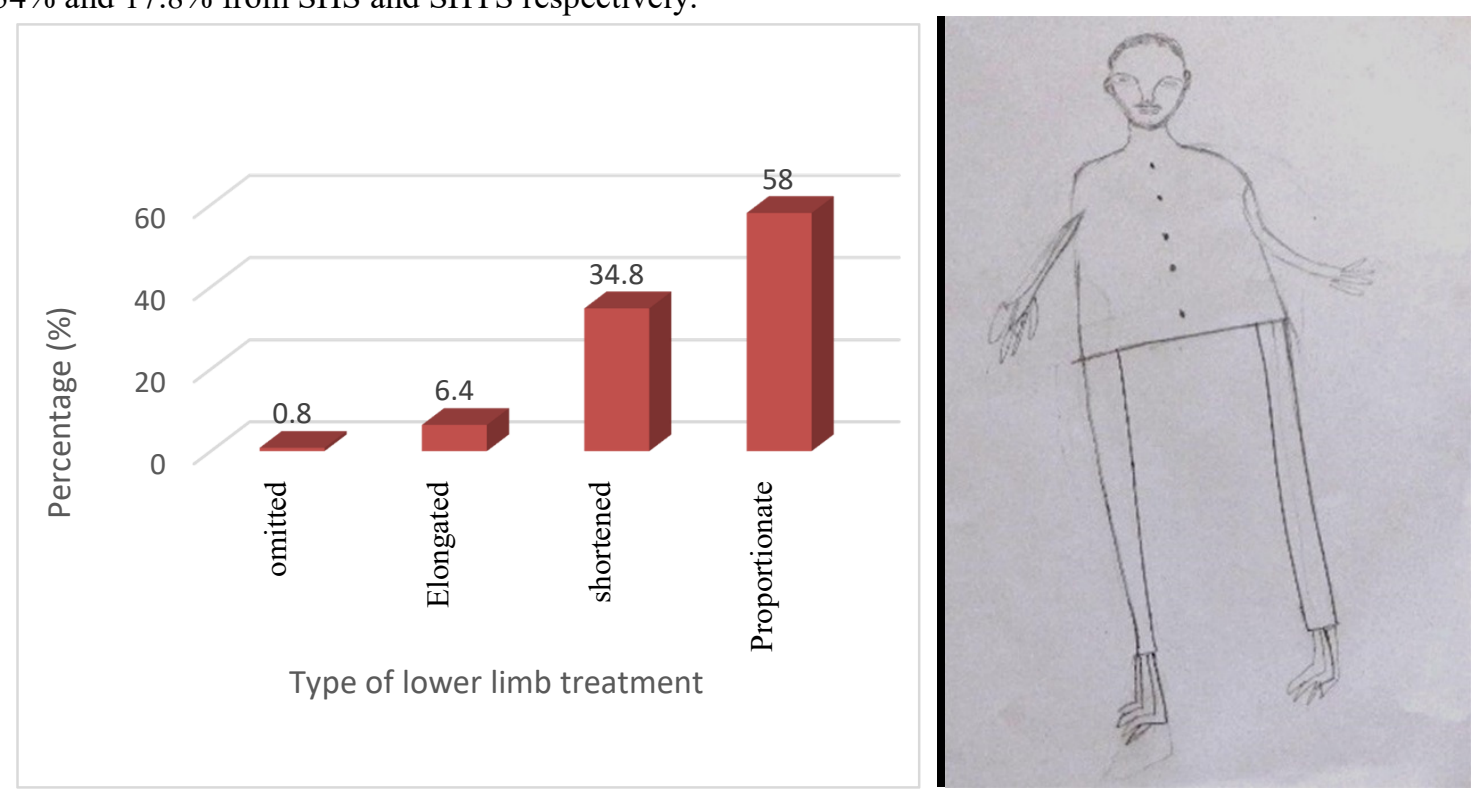

Figure 9: Treatment of lower limbs

Figure 10: Elongated lower limbs

\subsection{Breasts}

There were 148 (39.4\%) male figures, requiring no breasts. Out of the remaining 232 female figure drawings, 112 
$(49 \%)$ had no indications of breasts even though the figures were labelled as females as indicated in figure 8 . There were marks on $45(20.0 \%)$ drawings, which suggested indication of breasts; the breasts were either simply represented with a dot, a dot encircled by an oval, a "W" or two "U". regarding the placement, $44(19 \%)$ of the breasts were placed on the dresses of the figures. A cross tabulation showed that $28 \%$ of the female drawings made by males as opposed to $16.5 \%$ of the drawings made by females had the breasts placed on the dress. Only $27(12 \%)$ of the drawings had their breasts correctly placed as shown in figure 11.

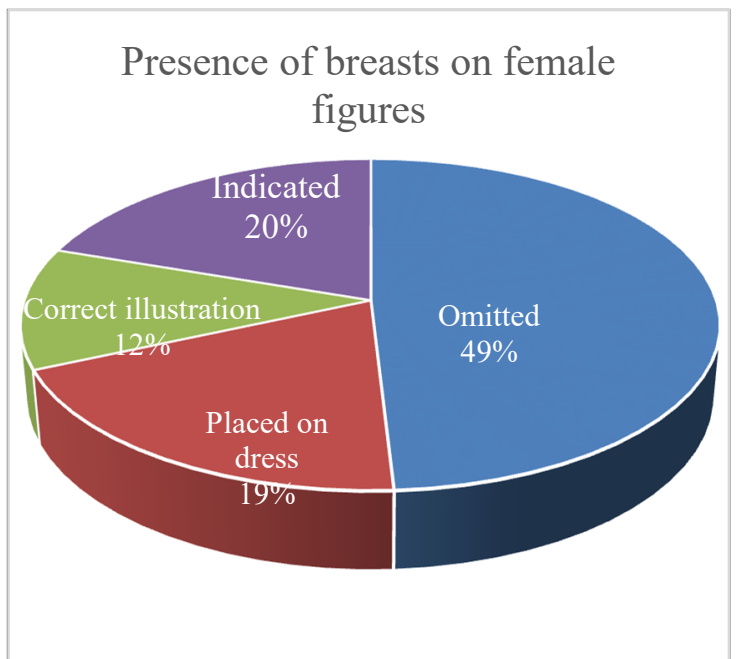

Figure 11: Presence of breast

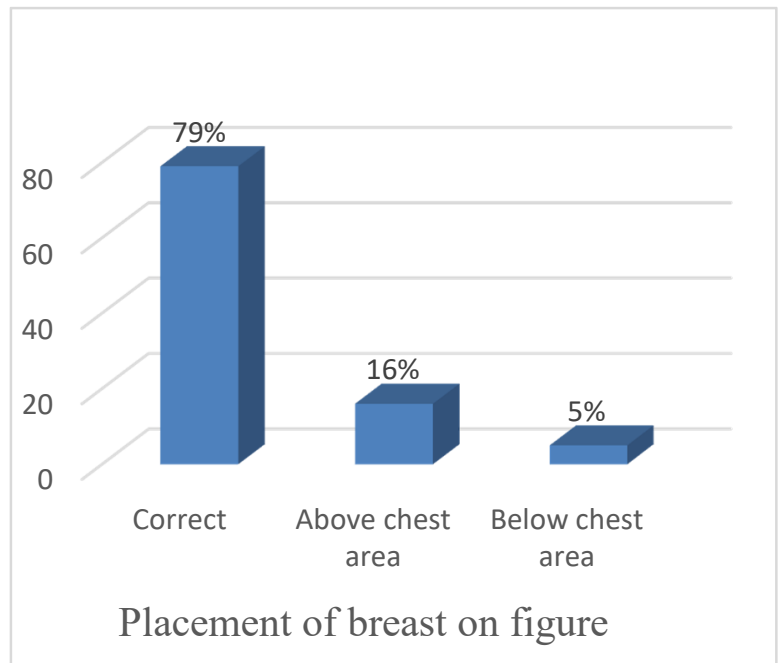

Figure 12: Placement of breast

The positioning of the breast was also an area of concern. Out of the drawings which had breasts, $16.0 \%$ had them placed above the chest area (Figure 12); some were just under the neck. A cross tabulation indicated that $8.6 \%$ of the drawings produced by the males had the breasts placed above the chest area as compared to $6.6 \%$ from the females. Drawings which had the breasts placed below the chest area constituted $5 \%$ and all of them were produced by males.

\subsection{Transparency}

As shown in figure $13,90.2 \%$ of the drawings were opaque while transparent drawings formed $9.8 \%$ of the total number of drawings produced (Figures 14 and 15). Out of the drawings which were transparent, $78.4 \%$ were produced by females while $21.6 \%$ were produced by males.

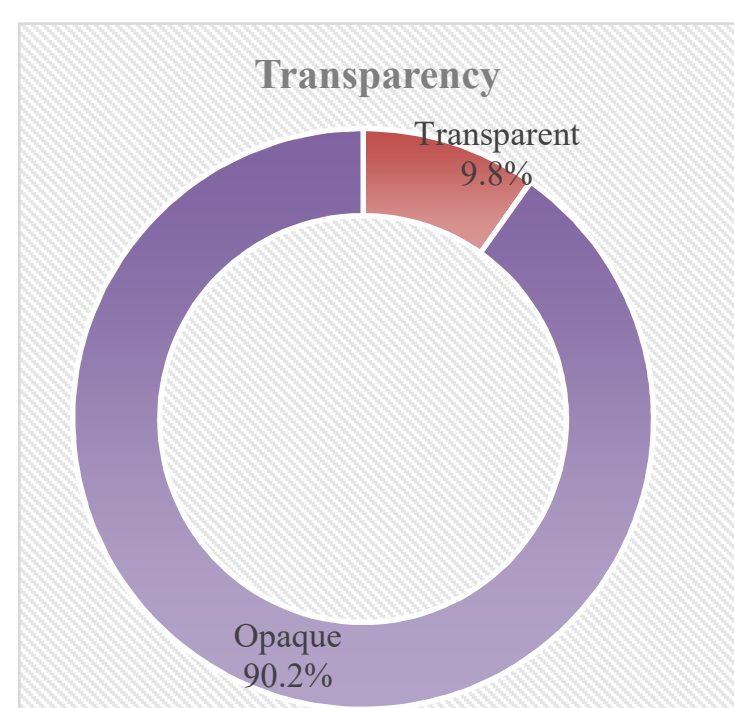

Figure 13: Figure transparency

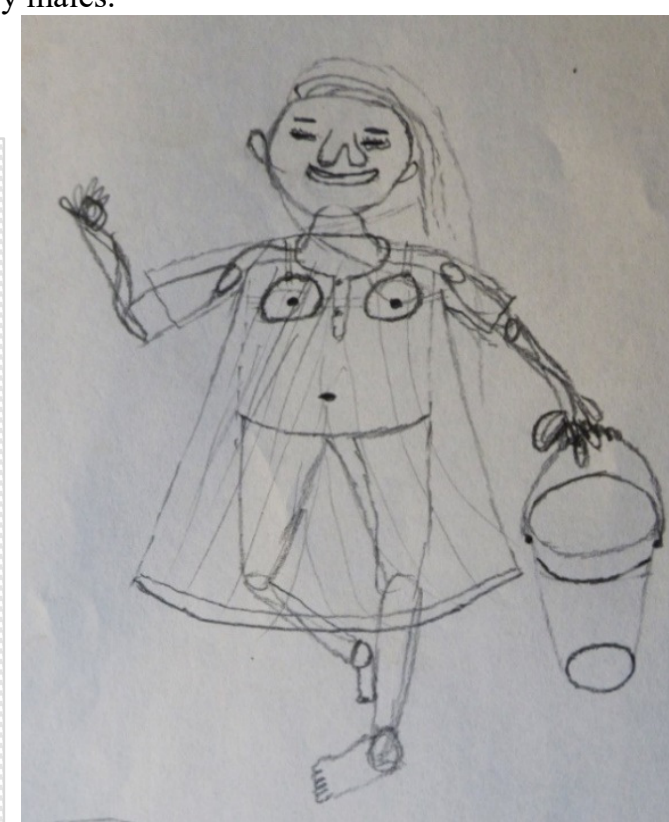

Figure 14: A transparent dress

\subsection{Use of space}

Majority of the drawings (87.5\%) had a good balance between positive and negative use of space, however, 47 $(12.5 \%)$ did not use the space proportionately: a few drew the image with too much negative space left around. 
This made their figures look small. Others who seemed to have miscalculated the length of their drawn figures simply drew till they were out of space and the figure run out of the paper (Figure 16). A cross tabulation on how each gender used their space showed no significant disparity between males and females. The statistics also showed that $96.2 \%$ of the students from Senior High Schools used their space well, followed by students from the Senior High Technical Schools (92.2\%), while those from Technical Schools had $80.0 \%$ of their works been proportional to the space provided.

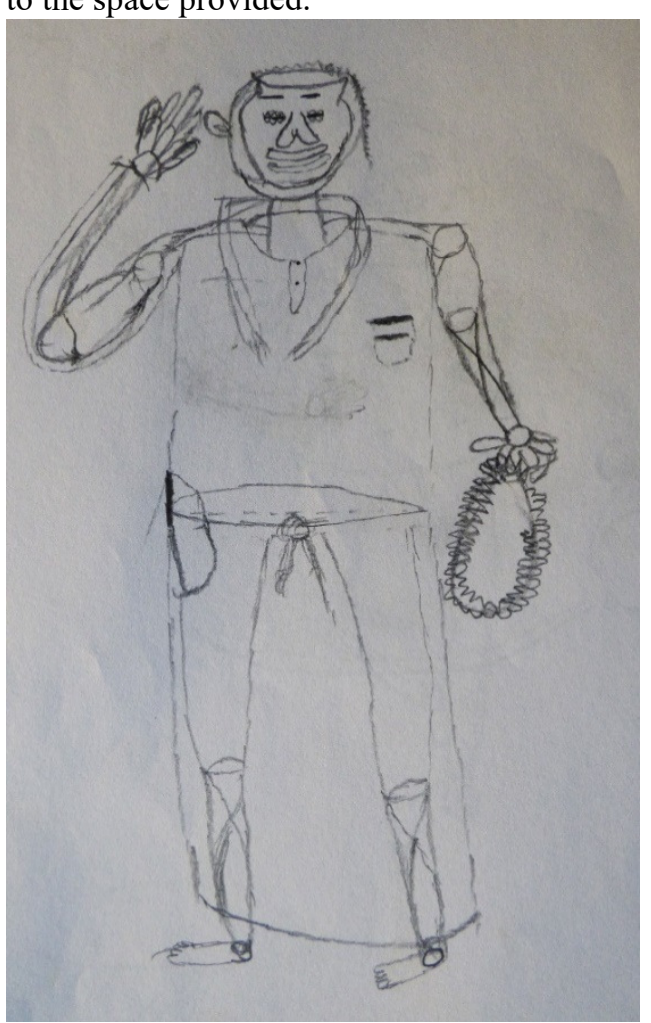

Figure 15: Figure transparency

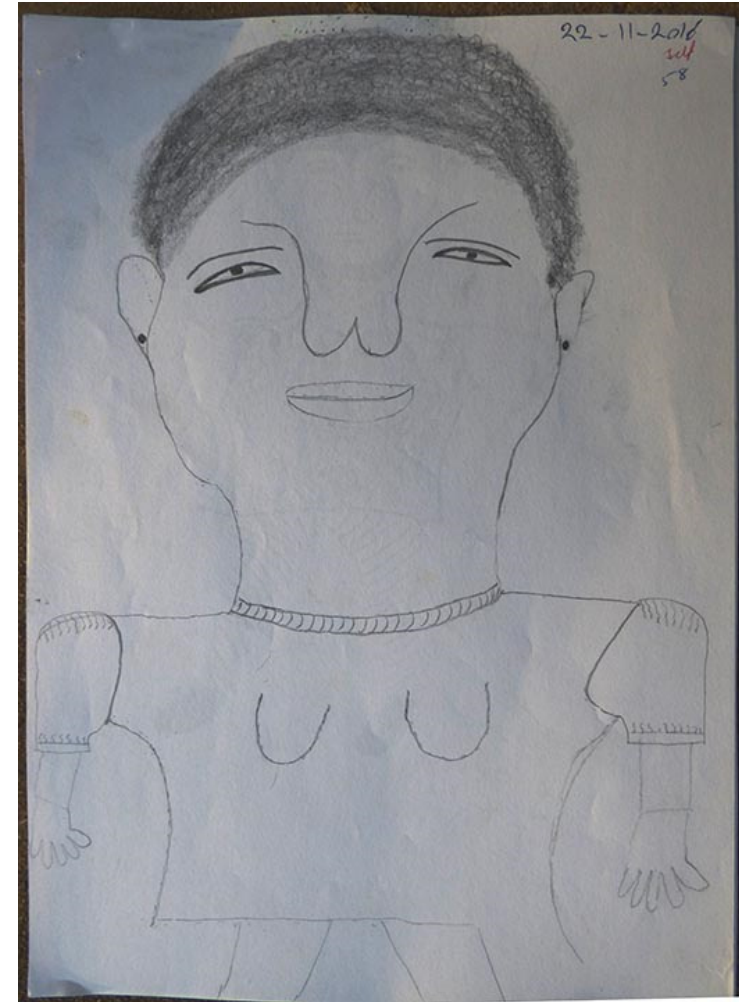

Figure 16: Poor use of space

\section{Conclusion}

The drawings produced by the adults in this study are not significantly different from children's drawings produced in Ghana in the studies of Adjei, Adongo \& Oppong (2016), Adjei, Oppong, \& Amponsah (2016), Enti (2008) and Osei, (2013). Also, the drawings produced by children from other countries such as Catte (1998), Malchiodi (2012) and Peterson et al., (1995) have similar characteristics to those produced in this study. The findings goes to support the assertions that as children grow above 10 years, they become dissatisfied with their drawings and as such become more critical. Others tend to draw more cartoon and comic figures as opposed to realistic human figures (Rubin, 2005 and Thomas \& Silk, 1990).

Figure drawing is a challenge to visual art graduates of the second cycle educational system in Ghana. This is evident in the rendition of almost all the human body parts. Even though it is a requirement by the syllabi that these students should be taught the drawing of human figures, the results showed that either the students did not grasp the lessons on figure drawing or probably they were inadequately taught or not taught at all.

Body parts which had most infractions included the nose, fingers and necks. Averagely, the students from the SHS produced works which had less blunders.

\section{Recommendations}

The figure drawing lessons taught at the second cycle institutions of the country needs to be revisited. This is because, a host of programmes pursued in art at the tertiary level requires the skill of human figure drawing or at least requires the knowledge of human anatomy. Also, students who might want to pursue careers in the visual art industry after SHS in areas such as Fashion designing, sculpture, painting, among others will require some degree of proficiency in human anatomical drawing to be able to meet the needs of creating products for human beings.

There should be workshops organised for teachers who teach art on the subject of human figure drawing. This will ensure that the teachers are well vested in human anatomical drawing dynamics and can most likely draw well. This will ensure that teachers possess the requisite skills in art to be able to impart them. It will also offer teachers who had no/little training in figure drawing to be able to master the subject.

It is also recommended that further studies be conducted to evaluate the teaching and learning of drawing, 
especially figure drawing at the second cycle institutions. Furthermore, there is the need to assess the qualifications and skills of teachers of this subject.

\section{References}

Adjei, D. A., Adongo, N., \& Oppong, C. (2016). Children of rainstorm: Art works by children who experienced the Bongo rainstorms. International Journal of Innovation and Applied Studies, 18(2), 483-493.

Adjei, D. A., Oppong, C., \& Amponsah, L. (2016). Children's Drawings with Genitals: Art Works from Children Who Co-Sleep with Adults. Art and Design Studies, 41, 5-11.

Adu-gyamfi, S., Donkor, W. J., \& Addo, A. A. (2016). Educational Reforms in Ghana: Past and Present. Journal of Education and Human Development, 5(3).

Amenuke, S.K., Dogbe, B.K., Asare, F.D.K., Ayiku, R.K., \& Baffoe, A. (1999). General Knowledge in Art. Accra: Inter Universe Printing Press

Boafo, A. R. (2010). Creative arts in crisis: Teaching and learning of creative arts in selected public primary schools in Kumasi Metropolis. (Unpublished master's thesis). Kwame Nkrumah University of Science and Technology, Kumasi, Ghana.

Bolgatanga Polytechnic (2012). Information for programme re-accreditation: HND Industrial Art. Ghana: Bolgatanga Polytechnic

Bolgatanga Polytechnic (2018, March 16). Bolgatanga Polytechnic admissions. Daily graphic, p42

Catte, M. (1998). Emotional Indicators in Children's Human Figure Drawings: An Evaluation of the Draw-APerson Test. University of York.

Curriculum Research Development Division (2010). Sculpture Teaching Syllabus for SHS. Ghana: Ministry of Education

Edusei, K. (1991). Significant Ghanaian Educational Innovations and Landmarks and their Socio- Cultural Impact. (Unpublished doctoral dissertation). Kwame Nkrumah University of Science and Technology, Kumasi, Ghana.

Edusei, K. (2004). An overview of visual art education in Ghana schools. Journal of Science and Technology, 24(2), 116-121.

Enti, M. (2008). Temperaments of children as expressed through their art. (Unpublished doctoral dissertation). Kwame Nkrumah University of Science and Technology, Kumasi, Ghana.

GWSonlineGH. (n.d.). WASSCE / WAEC visual art syllabus. Retrieved from https://www.ghanawebsolutions.com/serve.php?id=2382\&d=Visual-Art-Syllabus-WAEC-WASSCE

Kassah, J. K., \& Kemevor, A. K. (2016). The challenges of visual arts education in Ghana's Colleges of Education. International Journal of Scientific Engineering and Applied Science, 2(3), 87-98.

Legonconnect (2017). Admission requirements for Bolgatanga Polytechnic. Retrieved from www.legonconnect/admission-requirements-for-bolgatnag-polytechnic.

Malchiodi, C. (2012). Understanding children's drawings. New York: Guilford Press.

Osei, M. (2013). Illustration of self-concept through drawings: the perspective of the child in an orphanage. International Journal of Innovative Research \& Studies, 2(7), 761-778.

Peterson, L. W., Hardin, M., \& Nitsch, M. J. (1995). The use of children's drawings in the evaluation and treatment of child sexual, emotional, and physical abuse. Clinical Review, 4, 445-452.

Rubin, J. A. (2005). Child art therapy. Hoboken, NJ: John Wiley \& Sons.

Thomas, G. v., \& Silk, A. M. J. (1990). An introduction to the psychology of children's drawings. New York: New York University Press 